\title{
CHEMOSYMBIOSIS: TOWARDS AN INTEGRATED APPROACH FOR TRACKING TROPHIC STRATEGY IN THE FOSSIL RECORD
}

COBABE*, Emily, Department of Geology, University of Bristol, Wills Memorial Building, Queens Road, Bristol, BS8 1RJ, U.K.

Chemosymbiosis can be identified in fossil taxa and followed through the fossil record with some certainty if several independent criteria are met. No hard part morphology reliably reflects a chemosymbiotic lifestyle, but soft part morphology can be used to demonstrate that chemosymbiosis is primitive in some groups. Throughout the evolutionary history of a taxon, faunal and facies associations can provide support for a chemosymbiotic interpretation. Biogeochemical evidence from fossil organic matter may, in some cases, demonstrate the $\delta^{13} \mathrm{C}$ depletion recognized as being chemosymbiotic in origin.

Morphology of extant lucinacean bivalves indicates that the superfamily was primitively chemosymbiotic and suggests that the Ungulinidae and some of the Thyasiridae have secondarily lost their bacterial symbionts. This observation, along with facies and faunal data, suggests that the family Lucinidae has always been chemosymbiotic and that the Lucinidae are a reliable group to use in evaluating the paleobiological effects of chemosymbiosis.

Biogeochemical evidence does suggest that lucinid bivalves were chemosymbiotic in the past and stable isotope analyses remain the only direct method for evaluating chemosymbiosis in the fossil record. For taxa with no extant members but with interesting faunal or facies associations, $\delta^{13} \mathrm{C}$ of the organic matrix is still the best hope of evaluating this trophic strategy. 